\title{
Progress in Amorphous Silicon PV Technology: An Update
}

W. Luft, H. M. Branz

National Renewable Energy Laboratory

V. L. Dalal

Iowa State University

S. S. Hegedus

Institute of Energy Conversion

E. A. Schiff

Syracuse University

Prepared for the 13th NREL

Photovoltaics Program Review Meeting

May 16-19, 1995

Lakewood, Colorado

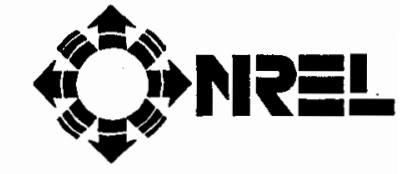

National Renewable Energy Laboratory 1617 Cole Boulevard Golden, Colorado 80401-3393

A national laboratory of the U.S. Department of Energy Managed by Midwest Research Institute for the U.S. Department of Energy under contract No. DE-AC36-83CH10093

Prepared under Task No. PV531101

July 1995 


\section{NOTICE}

This report was prepared as an account of work sponsored by an agency of the United States government. Neither the United States government nor any agency thereof, nor any of their employees, makes any warranty, express or implied, or assumes any legal liability or responsibility for the accuracy, completeness, or usefulness of any information, apparatus, product, or process disclosed, or represents that its use would not infringe privately owned rights. Reference herein to any specific commercial product, process, or service by trade name, trademark, manufacturer, or otherwise does not necessarily constitute or imply its endorsement, recommendation, or favoring by the United States government or any agency thereof. The views and opinions of authors expressed herein do not necessarily state or reflect those of the United States government or any agency thereof.

Available to DOE and DOE contractors from:

Office of Scientific and Technical Information (OSTI)

P.O. Box 62

Oak Ridge, TN 37831

Prices available by calling (615) $576-8401$

Available to the public from:

National Technical Information Service (NTIS)

U.S. Department of Commerce

5285 Port Royal Road

Springfield, VA 22161

(703) $487-4650$ 


\title{
PROGRESS IN AMORPHOUS SILICON PV TECHNOLOGY: AN UPDATE
}

\author{
W. Luft*, H. M. Branz*, V. L. Dalal†, S. S. Hegedusłł, \\ and E. A. Schiff§ \\ * National Renewable Energy Laboratory, 1617 Cole Blvd. Golden, CO 80401 \\ † Iowa State University, Ames, IA 50010 \\ $¥$ University of Delaware, Institute of Energy Conversion, Newark, DE 19716 \\ \$ Syracuse University, Syracuse, NY 13244-1130
}

\begin{abstract}
To reach the $15 \%$ stabilized efficiency goal for amorphous silicon (a-Si) modules by the year 2005, the National Renewable Energy Laboratory has established four research teams. The teams - with members from industry, universities, and NREL - have been in operation for 2.5 years now. Consensus has been reached that a triple-junction a-Si structure is needed to reach the efficiency goal. Performance parameter goals for the overall structure and the three component cells have been formulated. All four teams have generated their own development plans. Individual team progress relative to the plans is reported.
\end{abstract}

\section{INTRODUCTION}

Informed observers of energy markets generally believe that photovoltaics will not significantly penetrate the electric utility bulk-power sector until price and performance approach $\$ 50 / \mathrm{m}^{2}$ for $15 \%$ efficient modules in flat-plate systems [DeMeo 1991]. Present best stabilized efficiencies for amorphous silicon modules are about $10 \%$. There has been a consensus among the researchers funded by the National Renewable Energy Laboratory (NREL), that in order to achieve a 15\% stabilized efficiency, a triple-junction amorphous silicon structure is required. Consequently, the efforts under the NREL amorphous silicon research project have been directed toward such structures.

\section{OBJECTIVES}

The objectives of the DOE sponsored amorphous silicon PV research are to: 1) develop a cost-effective amorphous silicon PV technology to foster a viable amorphous silicon PV industry in the United States ensuring that this industry 
remains a world leader in the a-Si technology; 2) help the U.S. amorphous silicon PV industry to achieve the U.S. DOE PV Program fiscal year 1995 milestone of $10 \%$ stable efficiency commercial thin-film modules; 3) help the U.S. amorphous silicon PV industry to achieve $12 \%$ stable efficiency commercial thin-film modules by 1998; and 4) achieve $15 \%$ stable efficiency multijunction a-Si:H modules for large-scale electric utility use by the year 2005 .

\section{APPROACH}

To achieve the objectives in a timely and efficient manner, NREL established four research teams in November 1992: a Wide-bandgap Alloy Team, a Metastability and Mid-bandgap Alloy Team, a Low-bandgap Alloy Team, and a Multijunction Device Team [Luft 1993]. In the period of 1994-1995, these teams were joined with those of the Electric Power Research Institute, which had formed similar teams earlier in 1992. The joint teams consist of researchers from four industrial organizations, twelve universities, and NREL.

It is expected that coordinated team efforts with well defined mission objectives will lead to more rapid progress toward the $15 \%$ efficiency goal than a diffused effort by many independent researchers would [Peterson and Luft, 1993]. Having agreed on a triple-junction structure, a set of stabilized characteristics was adopted that must be achieved for the three component cells in the structure and for the combined structure to reach the goal of $15 \%$ stabilized module efficiency. These parameters are shown in Table 1. The parameters are applicable to a multibandgap structure with the approximate Tauc bandgaps for the components as indicated in the table. The goals for the multijunction cell are based on modeling for a $14 \%$ device with an a-SiGe:H midgap layer and then extrapolated to $16 \%$ cells ( $15 \%$ modules) [Guha et al. 1993].

The goals may change if the bandgap distribution is changed. The present status of corresponding parameters for small amorphous silicon cells is shown in parentheses in Table 1 and is based on cell data from the PV industry after 600 hours or more light soaking at $1000 \mathrm{~W} / \mathrm{m}^{2}$ and $50^{\circ} \mathrm{C}$. The mid-and low-bandgap small cells were degraded under illumination with filters. The best stabilized module efficiencies, as measured under a solar simulator, that have been reported so far are given in Table 2.

Each of the four teams is addressing a number of research issues that have been identified by the researchers to be essential to meet the long-term objectives. The individual teams have defined the problems that must be overcome to achieve the parameters indicated in Table 1, defined the root causes for the problems, and the countermeasures (research activities) to be taken. The most status of the urgent research activities is described in the following sections for the four teams. 
Table 1. Long-term amorphous silicon cell stabilized performance goals to meet the $15 \%$ module goal [Guha et al. 1993]

\begin{tabular}{|c|c|c|c|c|c|}
\hline $\begin{array}{l}\text { Component } \\
\text { Cell }\end{array}$ & $\begin{array}{l}\text { Bandgap } \\
(\mathrm{eV})\end{array}$ & $\begin{array}{l}v_{\text {oc }} \\
\text { (V) }\end{array}$ & FF & $\begin{array}{l}\mathrm{J}_{s c} \\
\left(\mathrm{~A}^{\prime} / \mathrm{m}^{2}\right)\end{array}$ & $\begin{array}{l}\text { Power } \\
\left(W / m^{2}\right)\end{array}$ \\
\hline $\begin{array}{l}\text { Wide- } \\
\text { Bandgapt }\end{array}$ & $1.9-2.0$ & $\begin{array}{l}1.10 \\
(0.98) \mathrm{d}) \\
(0.97) \mathrm{c})\end{array}$ & $\begin{array}{l}0.75 \\
(0.68) \text { d) } \\
(0.72) c)\end{array}$ & $\begin{array}{l}>82 \\
(80) d) \\
(73) c)\end{array}$ & $\begin{array}{l}68 \\
(53) d) \\
(50) c)\end{array}$ \\
\hline \multirow[t]{2}{*}{$\begin{array}{l}\text { Mid- } \\
\text { Bandgap(a)† }\end{array}$} & $\begin{array}{l}1.70-1.75 \\
\text { a-Si:H }\end{array}$ & $\begin{array}{c}0.95 \\
(0.87) c)\end{array}$ & $\begin{array}{l}0.75 \\
(0.61) c)\end{array}$ & $\begin{array}{l}>84 \\
(62) \mathrm{c})\end{array}$ & $\begin{array}{c}60 \\
(33) \mathrm{c}) \\
\end{array}$ \\
\hline & $\begin{array}{l}\text { 1.60-1.65 } \\
\text { a-SiGe:H }\end{array}$ & $\begin{array}{l}0.89 \\
(0.74) c)\end{array}$ & $\begin{array}{l}0.70 \\
(0.60) c)\end{array}$ & $\begin{array}{l}84 \\
(76) c)\end{array}$ & $\begin{array}{c}52 \\
(35) c)\end{array}$ \\
\hline $\begin{array}{l}\text { Low- } \\
\text { Bandgap(b) }\end{array}$ & $1.40-1.45$ & $\begin{array}{l}0.68 \\
(0.66) \mathrm{c})\end{array}$ & $\begin{array}{l}0.68 \\
(0.55) \mathrm{c})\end{array}$ & $\begin{array}{l}>86 \\
(98) \text { c) }\end{array}$ & $\begin{array}{l}>40 \\
(36) \mathrm{c})\end{array}$ \\
\hline $\begin{array}{l}\text { Triple-junction } \\
\text { Devices }\end{array}$ & & $\begin{array}{l}2.60 \\
(2.44) c) \neq\end{array}$ & $\begin{array}{l}0.72 \\
(0.61) c) \neq\end{array}$ & $\begin{array}{l}>83 \\
(77) c) \neq\end{array}$ & $\begin{array}{l}160 \\
(115) c) \ddagger\end{array}$ \\
\hline
\end{tabular}

(a) under $\lambda>530 \mathrm{~nm}$ light as seen by the mid-cell in a triple-stack, (b) under $\lambda>630 \mathrm{~nm}$ light as seen by the bottom-cell in a triple-stack, (c) United Solar Systems Corporation data, (d) Solarex Corporation data not on $\mathrm{Cr}$, but with a thick $n$ layer, $\dagger$ with $\mathrm{Cr}$ reflector for low reflectance, $¥$ after 360 hours light soaking.

Table 2. Best amorphous silicon module stabilized efficiencies (measured with a solar simulator after 600-2000 hours of light soaking)

\begin{tabular}{|c|c|c|c|c|}
\hline Manufacturer & Module Type & $\begin{array}{l}\text { Area } \\
\left(\mathrm{cm}^{2}\right)\end{array}$ & $\begin{array}{l}\text { Power } \\
\text { (W) }\end{array}$ & $\begin{array}{l}\text { Efficiency } \\
(\%)\end{array}$ \\
\hline \multirow[t]{3}{*}{ Solarex } & $\mathrm{Si} / \mathrm{SiGe}$ & 842 & 7.7 & $9.1 \S$ \\
\hline & $\mathrm{Si} / \mathrm{SiGe}$ & 3,432 & 26.9 & $7.8 \S \dagger$ \\
\hline & $\mathrm{Si} / \mathrm{Si} / \mathrm{SiGe}$ & 863 & 7.6 & $8.8 \dagger$ \\
\hline \multirow{3}{*}{$\begin{array}{l}\text { United Solar } \\
\text { Systems Corporation }\end{array}$} & $\mathrm{Si} / \mathrm{Si}$ & 3,676 & 22.8 & $6.2 \ddagger$ \\
\hline & $\mathrm{Si} / \mathrm{SiGe}$ & 902 & 8.6 & $9.5 \dagger$ \\
\hline & $\mathrm{Si} / \mathrm{Si} / \mathrm{SiGe}$ & 903 & 9.2 & $10.2 \S$ \\
\hline Energy Conv. Devices & $\mathrm{Si} / \mathrm{Si} / \mathrm{SiGe}$ & 3,906 & 30.6 & 7.8 \\
\hline Fuji & $\mathrm{Si} / \mathrm{Si}$ & 1,200 & 10.7 & 8.9 \\
\hline \multirow[t]{3}{*}{ Advanced PV Systems } & $\mathrm{Si}$ & 11,634 & 51.2 & $4.4 \ddagger$ \\
\hline & $\mathrm{Si} / \mathrm{Si}$ & 848 & 6.0 & $7.1 \dagger$ \\
\hline & $\mathrm{Si} / \mathrm{Si}$ & 11,522 & 53.0 & $4.6 \ddagger$ \\
\hline
\end{tabular}

$\dagger$ Not verified by NREL measurements, $¥$ Outdoor exposure and measurement, § Not lightsoaked at NREL 


\section{WIDE-BANDGAP ALLOY TEAM}

The Wide-bandgap Alloy Team is addressing problems of low $\mathrm{V}_{\mathrm{oc}}, \mathrm{FF}$, and $\mathrm{J}_{\mathrm{sc}}$ for a-SiC:H alloys. The team is seeking to improve both the doped window-layer and undoped, wide-bandgap absorber layers required for a triple-junction design. (See Figure 1). Only tho top six are being pursued.

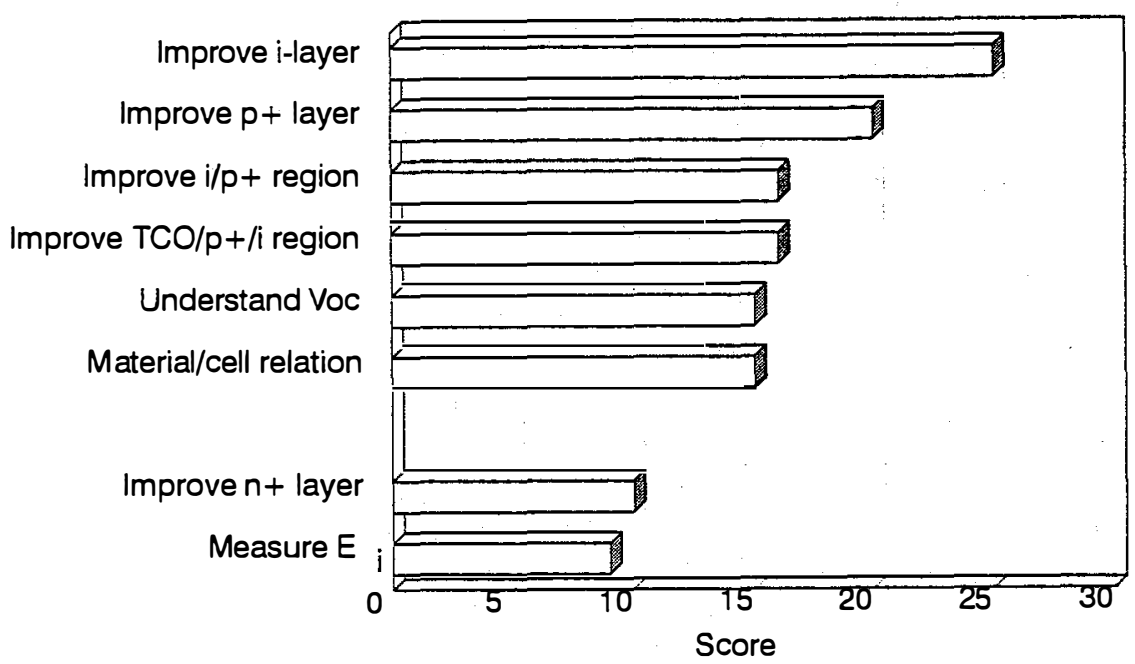

Figure 1. Wide-bandgap team research priorities

The team aims to demonstrate a $68 \mathrm{~W} / \mathrm{m}^{2}$ solar cell which utilizes only the blue/green portion of the solar spectrum. The exact spectral region available to this cell is determined by the detailed engineering of a triple-junction a-Si based solar cell; the provisional requirement is $\lambda<530 \mathrm{~nm}(h v>2.4 \mathrm{eV})$, corresponding to a maximum short circuit current density of about $82 \mathrm{~A} / \mathrm{m}^{2}$. The targets for the fill-factor and open-circuit voltage are 0.75 and $1.10 \mathrm{~V}$, respectively.

All three industrial members of the team have demonstrated solar cells which are fairly close to these wide-bandgap targets. The corresponding cell parameters for two groups are collected in Table 1 . Two very different approaches were taken. Solarex cells use the $p-i-n$ deposition sequence, with a-SiC:H intrinsic and $p^{+}$ layers [ $\mathrm{Li}$ et al. 1993]; the nominal, "Tauc" bandgap for the intrinsic layer in their best cell was $1.90 \mathrm{eV}$. United Solar Systems Corp. and Energy Conversion Devices, Inc. have each demonstrated $n-i-p$ deposition sequence wide-bandgap cells based on an a-Si:H intrinsic layer prepared using substantial hydrogen dilution during plasma deposition and a microcrystalline-Si $p^{+}$layer [Yang et al. 1994, Deng 1995].

In fact there are additional grounds for optimism that the targets for the widebandgap cell can be surpassed in the near future. A simple empirical correlation exists governing the largest reported open-circuit voltages of a-Si- and a-SiGe- 
based solar cells with the bandgaps $E_{\mathrm{G}}$ of their intrinsic layers [Crandall and Schiff, 1995]:

$$
V_{\mathrm{OC}}=\left(E_{\mathrm{G}} / e\right)-0.80\left(1.4<E_{\mathrm{G}}<1.8 \mathrm{eV}\right)
$$

The existence of this correlation strongly supports the view that the principal limitation to $V_{\mathrm{OC}}$ in narrower bandgap cells are the bandtail properties of their intrinsic layers. However, extension of this correlation indicates that $1.90 \mathrm{eV}$ material should be capable of generating $V_{\mathrm{OC}}=1.10 \mathrm{~V}$, and indeed Y.-M. Li proposed factor limiting $V_{\mathrm{OC}}$ to $0.98 \mathrm{~V}$ in the Solarex a-SiC:H cells was the $p^{+}$ layer [Li et al. 1993].

The wide-bandgap team has therefore adopted an action plan which places the highest priorities on improving both wide-bandgap intrinsic layers and window $\left(p^{+}\right)$layers in $p-i-n$ solar cells, as evidenced in particular by improved $V_{\text {OC. }}$. In addition to the work of the industrial team members noted above, there are several efforts underway at the team's university laboratories.

At Pennsylvania State University, the research groups of R. Collins and C. R. Wronski are working to exploit the capability of monolayer-sensitive, in-situ monitoring of the growth of a-Si based films to improve wide-bandgap solar cell performance [Collins et al. 1995]. One example of the success of this technique was its detection of a thin "boron-silicide" layer at the $p^{+} / i$ interface of a $p-i-n$ solar cell. Using spectroscopic ellipsometry to monitor this layer, these researchers showed that deposition procedures which minimized its extent yielded an increase of about $0.1 \mathrm{~V}$ in $V_{\text {OC }}$. A similar monitoring approach is being applied to developing materials based on "chemical annealing" procedures, in which the advancing interface of a growing a-Si-based films is exposed to atomic hydrogen. produced by a hot filament incorporated into the plasma deposition reactor. In parallel with this work on novel deposition procedures exploiting insitu ellipsometry, these groups are working to demonstrate a baseline solar cell with properties comparable to the work by the industrial team members.

At the University of Illinois-Urbana Champaign, the research group of $\mathrm{J}$. Abelson is developing a-Si-based materials and magnetron sputtering solar cells. The group has recently demonstrated a $p-i-n$ solar cell based entirely on magnetron sputtered materials. One aspect of this cell illustrates the potential advantage of the magnetron sputtering approach. Scientists working on a-Si-based cells deposited in the sequence TCO/p/i/n need to work around the fact that transparent conducting oxide materials such as $\mathrm{SnO}_{2}$ can be damaged by the plasmas used to deposit the $p^{+}$layer of the cell, in particular by the atomic hydrogen and other radical species generated in the plasma. In the magnetron sputtered cell, Abelson's group exploited the fact that a thin, unhydrogenated a-Si layer can be sputtered onto the TCO. The deposition of this layer does not damage the TCO, and in fact protects it from the subsequent deposition of a hydrogenated $p$ layer. The unhydrogenated layer does not add significantly to the 
series resistance of the cell, possibly because it becomes hydrogenated during the subsequent processing.

At Syracuse University the research group of E. A. Schiff is studying plasma deposited boron-phosphide films as a possible alternative to a-Si based films for the top, window-layer of the cell. Because of its relatively large bandgap, crystalline BP is much more transparent than either c-Si or a-Si. The group has demonstrated amorphous BP layers which are also more transparent than current window layers, but adequate electrical properties have not yet been achieved.

In conjunction with this work on improvement in cells and materials, the wide bandgap team seeks to develop a better understanding of the wide bandgap materials and of how their properties ultimately determine the cell parameters. One of the first approaches to widening the bandgap of a-Si was alloying with carbon. The resulting materials are fairly clearly inferior to unalloyed a-Si, although a-SiC: $\mathrm{H}^{+}$layers are successfully used in $p-i-n$ structure cells. One insight into the reasons for the problems with $\mathrm{C}$-alloying has emerged from work at the Colorado School of Mines, where D. Williamson's group has used smallangle X-ray scattering (SAXS) to demonstrate that a-SiC:H alloys from several laboratories all exhibit a much increased nanostructure [Williamson et al. 1995] compared to unalloyed materials. This nanostructure is plausibly the root cause for the increased defect density in a-SiC: $\mathrm{H}$ materials and perhaps also for the difficulty in making microcrystalline $\mathrm{SiC}: \mathrm{H}$ materials.

The second thrust of the wide bandgap team's efforts to understand the workings of the solar cells is to develop a better insight into the origins of $V_{\mathrm{OC}}$; this effort is particularly important for the wide-bandgap cell, where there is initial evidence that $V_{\mathrm{OC}}$ is not increasing proportional to $\mathrm{E}_{\mathrm{G}}$ above $1.8 \mathrm{eV}$ as expected from the Eq. 1 correlation (for cells with intrinsic layers with $E_{\mathrm{G}}<1.8 \mathrm{eV}$ ) [Li et al. 1993, Crandall \& Schiff, 1995]. There is a continuing effort in C. R. Wronski's group at Pennsylvania State University to distinguish between the mobility and optical bandgaps of wide-bandgap materials; it is not clear at present whether mobility gaps, which control the electrical properties of a solar cell, increase as rapidly as do optical gaps for wide bandgap materials. This effect might then explain the failure of $V_{\mathrm{OC}}$ to rise as fast as anticipated. At Syracuse University, E. A. Schiff's group is working to use electroabsorption to determine the built-in potential $V_{\mathrm{BI}}$ established by the $p^{+}$and $n^{+}$layers of solar cells. Although straightforward estimates of $V_{\mathrm{BI}}$ from the electrical properties of the $p^{+}$and $n^{+}$layers are at least $1.3 \mathrm{~V}$, which is larger than the best values for $V_{\mathrm{OC}}$, estimates of $V_{\mathrm{BI}}$ from electroabsorption and electrical measurements in cells are lower -- about $1.05 \mathrm{~V}$ [Wang et al. 1994]. The resolution of this apparent conflict is very important in determining whether improvements in doped layers or intrinsic layers should be the highest priority for wide-bandgap cell research. 


\section{METASTABПITY AND MID-BANDGAP ALLOY TEAM}

The Metastability and Mid-Bandgap Alloy Team is addressing the need for improved 1.70 to $1.75 \mathrm{eV}$ a-Si:H and 1.60-1.65 eV a-SiGe:H solar cells with high stability against light-induced degradation. The team is working on problems in three areas: 1) understanding and overcoming metastable degradation in materials, 2) understanding and overcoming metastable degradation in solar cell structures, and 3) reducing the bandgap for a-Si:H. The specific research activities in order of priority are shown in Figure 2. Only the top six activities are actively pursued.

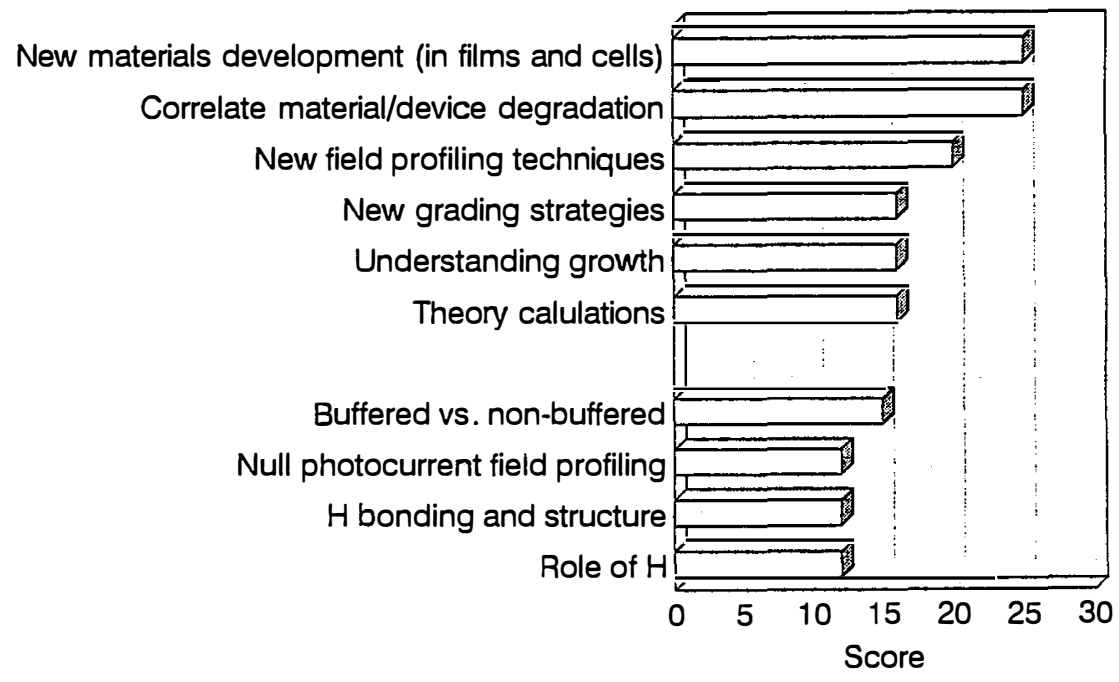

Figure 2. Mid-bandgap team research priorities

The team's highest priority is to deposit novel materials that will improve a-Si:H solar cell stability and to demonstrate this stability in laboratory-scale devices. The new materials must have improved stability against light-induced degradation and/or reduced bandgaps compared to standard glow-discharge (GD) a-Si:H. We are presently investigating three new deposition approaches with potential to satisfy these goals. These are hot-wire (HW) a-Si:H, electron-cyclotron-resonance (ECR) a-Si:H and H-diluted glow-discharge a-Si:H. We focus in this paper on our progress in this high priority research toward more stable devices.

The hot-wire effort is led by NREL team members H. Mahan and R. Crandall. In the HW deposition, a hot filament of $\mathrm{W}$ wire decomposes silane gas and an a-Si:H film grows on a heated substrate. The best HW films were shown to have both a reduced bandgap and improved stabilized properties. A $5.5 \%$ efficient $n-i$ $p$ solar cell grown on stainless steel with a HW i-layer was fabricated and has now been light-soaked for 4000 hours through a Pd contact (160 hours of 1-sunequivalent soaking) without exhibiting any significant light-induced degradation. [Mahan et al., 1995] A comparable device with a GD $i$ layer degraded more than $20 \%$ in its conversion efficiency under the same light soak. 
Present efforts are focused on increasing the initial conversion efficiency of HW solar cells. Team members from United Solar Systems Corp. are assisting NREL to speed up this optimization effort. HW devices are a significant challenge because the deposition temperature of the most stable HW material is about $375^{\circ} \mathrm{C}$, roughly $150^{\circ} \mathrm{C}$ higher than in GD. At these temperatures, there are problems with diffusion of $\mathrm{H}$ and of dopants within the films; special surface treatments and temperature profiling are required.

The HW material is studied by various team members in order to better understand its properties and determine which growth conditions yield the most promising films. The University of Oregon (D. Cohen), University of California (R. Braunstein) and NREL groups have established that HW films containing about 2 at.\% $\mathrm{H}$ show remarkable stability and have a bandgap about $0.12 \mathrm{eV}$ below that of GD a-Si:H [Kwon et al., 1995]. The University of North Carolina group (D. Han) finds nuclear magnetic resonance evidence that the $\mathrm{H}$ bonding structure of HW films is significantly different from that of GD material.

The Iowa State University group (V. Dalal) has shown improved-stability material and solar cells from ECR-deposited a-Si:H. In this technique, an ECR hydrogen plasma is used to decompose silane gas onto a substrate, again heated to about $375^{\circ} \mathrm{C}$. Under illumination, the ECR films degrade significantly less than conventional GD a-Si:H. Despite the high substrate temperature, Iowa State University has demonstrated $7.5 \%$ efficient ECR $p-i-n$ devices on glass substrates that are considerably more stable than comparable GD solar cells. Present work focusses upon reducing the bandgap of the best ECR a-Si:H to about $1.6 \mathrm{eV}$.

The Penn State University (C. Wronski and R. Collins) and Solarex groups collaborate to study GD a-Si:H made from silane highly diluted with hydrogen gas (e.g., 20:1 dilution). Both groups make films and devices with H-dilution that are more stable than those made from undiluted silane gas. They also find that complete stabilization of the films and devices is reached after less than 100 hours of 1-sun light soaking [L. Yang and L. Chen, 1994]. This contrasts sharply with undiluted GD material and devices that continue degrading even after 1000 hours light-soaking. The good correlation observed between the film and device properties suggests the importance of stabilizing film properties to improve devices.

The NREL group discovered that they could reproduce the improved stability of $\mathrm{H}$-diluted devices even if they restricted the $i$ layer $\mathrm{H}$-dilution to a region within about $20 \mathrm{~nm}$ of the $p-i$ interface [Q. Wang, et al., 1995]. Through the team interaction, this work was adapted by L. Yang and coworkers at Solarex to improve the average deposition rate of their most stable devices. Solarex found that high $\mathrm{H}$-dilution in the near-interface region (together with low $\mathrm{H}$ dilution in the rest of the cell) enabled them to grow solar cells with stabilized efficiency equal to their best high $\mathrm{H}$-dilution cells. Because high $\mathrm{H}$-dilution slows a-Si:H growth, this two-step approach to $\mathrm{H}$ dilution reduces the total device deposition time and could be used to improve manufacturing throughput at Solarex. 


\section{LOW-BANDGAP ALLOY TEAM}

The Low-bandgap Alloy Team is concentrating on a-SiGe:H alloys with 1.40$1.45 \mathrm{eV}$ bandgap. It addresses three main problems: 1) poor quality of materials, 2 ) poor devices, and 3) poor understanding of the stability issue. The major goal of the team is to achieve more stable, higher quality a-SiGe:H alloys in the $1.40-1.45 \mathrm{eV}$ bandgap range. This bandgap range is selected because it generates the correct $\mathrm{J}_{\mathrm{SC}}$ needed for current matching under the solar spectrum for a triple-junction cell and also because this range of alloys gives reasonable electronic properties and avoids the problems associated with excessive broadening of the Urbach tails in amorphous materials. The team recognized that the major problems lie with poorer material properties of a- $(\mathrm{Si}, \mathrm{Ge}): \mathrm{H}$ when compared with the properties of a-Si:H, and consequently, the primary research priority was to improve the material. The research effort was focussed on growing and understanding improved materials, including measuring the material properties in device-like structures such as $p-i-n$ diodes and Schottky barriers. Another area deemed important for improving the performance is in design, modeling, and analysis of improved solar cell structures, including graded-gap structures (See Figure 3).

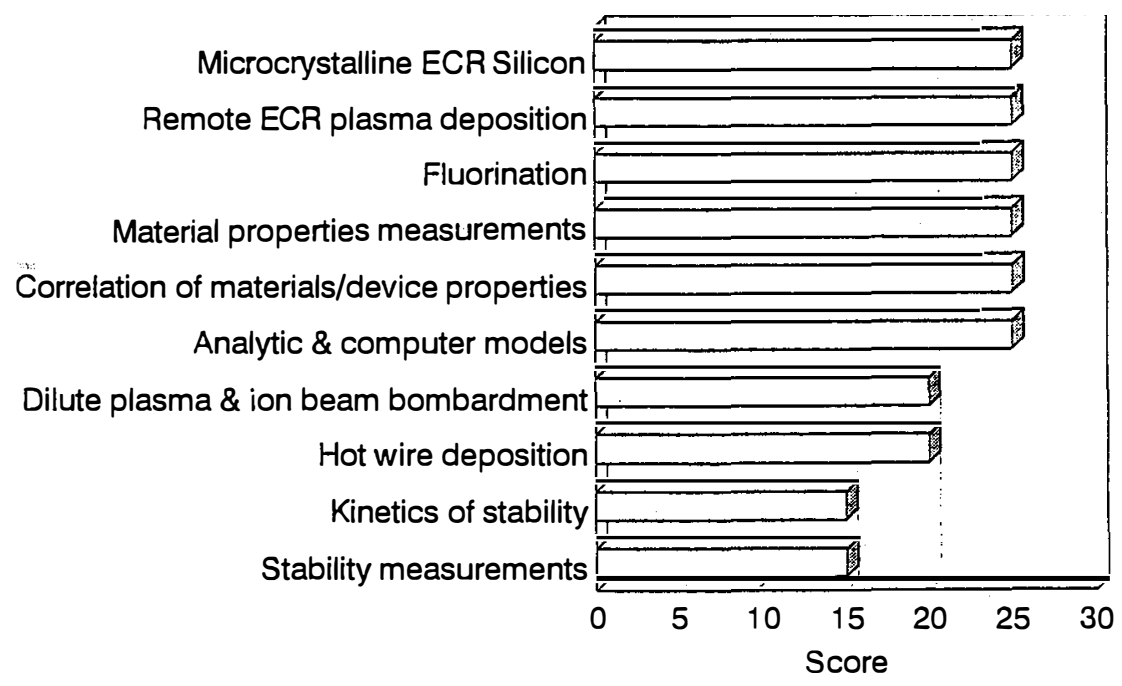

Figure 3. Low-bandgap team research priorities

\section{New material growth techniques}

During the past 18 months, two new material growth techniques were used to produce a-(Si,Ge):H material that appears to have better opto-electronic properties. These were hot wire and remote low pressure ECR plasma techniques.

Hot wire. A group at NREL, led by $\mathrm{H}$. Mahan, successfully grew a- $(\mathrm{Si}, \mathrm{Ge}): \mathrm{H}$ material of $1.5 \mathrm{eV}$ bandgap using the hot wire technique used earlier for a-Si:H [Mahan et al. 1991]. The properties achieved in the film are shown in Table 3. 
A particularly noteworthy feature is the ability to grow a low-gap film (1.49 eV Tauc gap) using only $21 \% \mathrm{Ge}$ in the film, as compared with the normal $30 \%$ required for glow-discharge deposition of a film with a similar bandgap. The high hole diffusion length $(113 \mathrm{~nm})$, and the low value of Urbach energy $(51 \mathrm{meV})$ are also noteworthy, since they indicate a high film quality.

Table 3. Properties of a-(Si,Ge):H films grown using hot wire techniques [NREL]

Tauc Gap: $1.49 \mathrm{eV}$

Composition: $21 \% \mathrm{Ge}$

Photo/dark conductivity ratio: $1 \times 10^{4}$

Diffusion length: $113 \mathrm{~nm}$

Urbach energy: $51 \mathrm{meV}$

Absorption coefficient (@1.0 eV): $2 \mathrm{~cm}^{-1}$

Remote ECR growth. It was shown earlier by the group led by Dalal at Iowa State University that remote low-pressure growth of a-Si:H films using electroncyclotron-resonance (ECR) techniques produces high quality, more stable films than glow discharge [Dalal et al., 1994]. They have now extended this technique to grow high quality a-( $\mathrm{Si}, \mathrm{Ge}): \mathrm{H}$ films, using a He ECR discharge. In Fig. 4, values of subgap absorption coefficient, $\alpha$, and the Urbach energy, $E_{o v}$, of valence band tails in these films are plotted as a function of the Tauc gap, and compared to corresponding values in glow-discharge deposited films. It is clear from Fig. 4 that the ECR films appear to have significantly better properties at a given Tauc gap than comparable glow-discharge deposited films. Dalal et al. (1994) have also found that the Ge content in these ECR films is much lower than in comparable bandgap glow-discharge films. The group plans to use their previously developed device fabrication techniques, described above in the Metastability and Midgap team's section to grow all-ECR a-( $\mathrm{Si}, \mathrm{Ge}): \mathrm{H}$ devices.

\section{Material Characterization Techniques}

A major task has been to measure material properties of relevance to devices, preferably in device-like structures. To this end, the group at the University of Oregon, led by D. Cohen, has systematically measured properties (such as, Urbach energies and mid-gap defect densities) using Schottky barrier capacitance techniques in a-( $\mathrm{Si}, \mathrm{Ge}): \mathrm{H}$ materials deposited on c-Si substrates [Zhong et al., 1994]. They find that the defect densities increase as Ge content increases, but that different deposition techniques give different results. (See Fig. 5.) They also find that material deposited under strong ion bombardment appears to have lower defect densities, the defects appear to be different in terms of their capture 

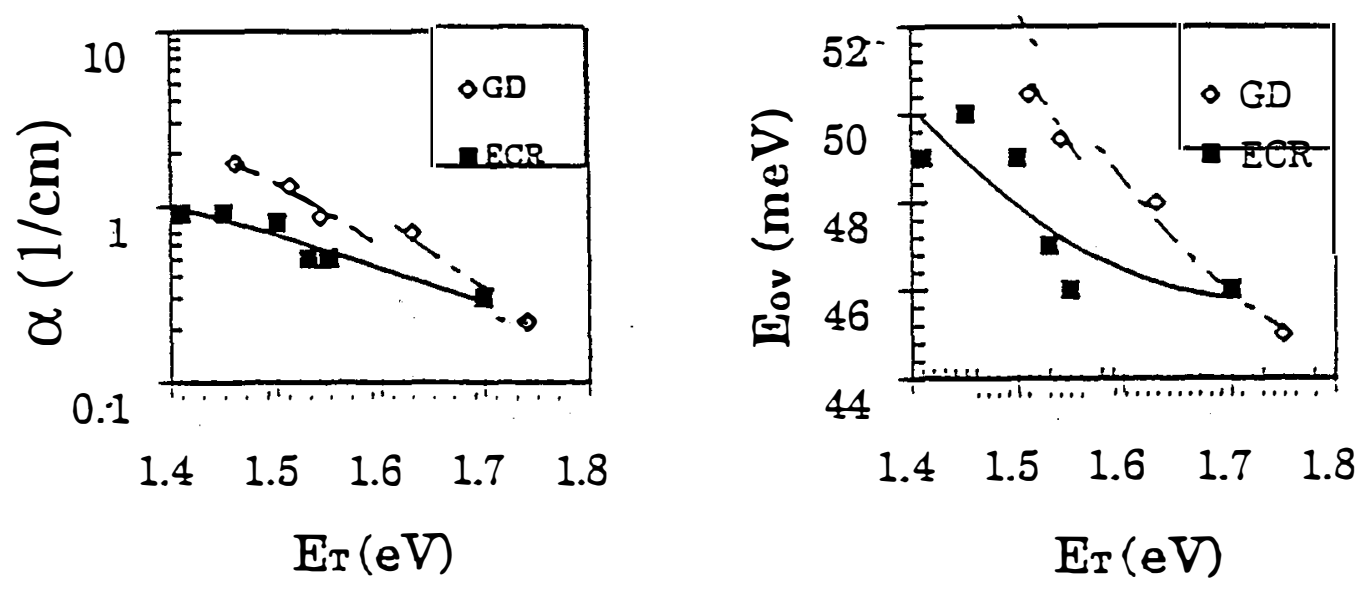

Figure 4. Subgap $\alpha$ and Urbach energy as a function of Tauc gap in a-(Si,Ge):H alloys produced by ECR and glow discharge.

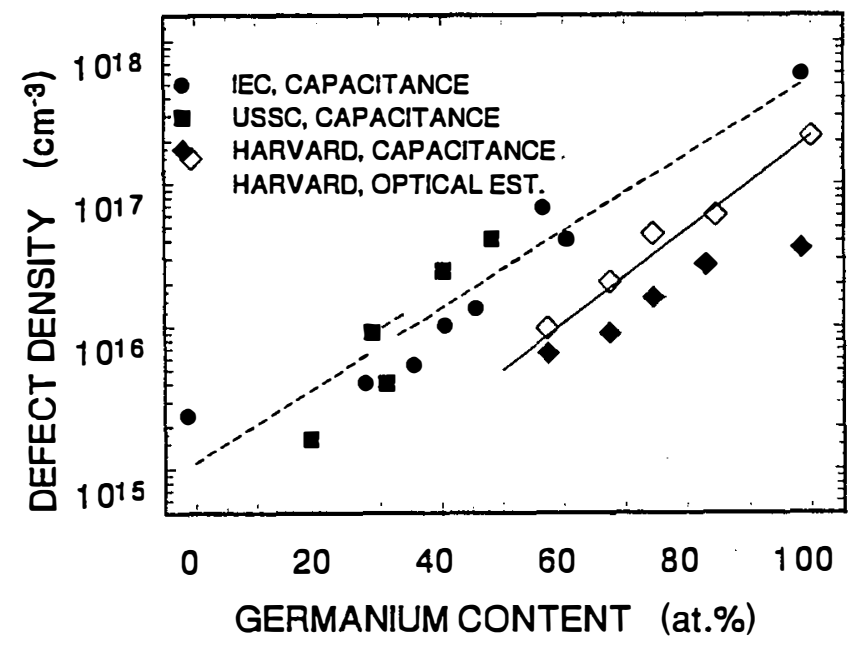

Figure 5. Defect density vs. Ge content of a-(Si,Ge):H alloys [Zhong et al. 1995]. Defects determined by capacitance or optical absorption. IEC material by photoCVD, USSC and Harvard materials by GD.

cross-sections for holes than materials deposited without ion bombardment. In particular, the defects in ion bombarded materials appear to be hindering hole transport much more than in materials which did not have significant ion bombardment. A major discovery by the Oregon group has been that the $\mathrm{a}-(\mathrm{Si}, \mathrm{Ge}): \mathrm{H}$ material, because of its intrinsically higher degree of disorder, has both charged and neutral defects as predicted by theory.

Another extensively used technique has been small-angle $\mathrm{x}$-ray scattering (SAXS), which has been very effective in detecting small voids in materials 
[Williamson et al., 1989]. This work was done by a group led by Don Williamson at Colorado School of Mines. They find that the best device material, namely that produced by the USSC group [Yang and Chen, 1994], shows no evidence of clustered $\mathrm{Si}-\mathrm{Si}$ or $\mathrm{Ge}-\mathrm{Ge}$ bonds, and that the material appears to have elongated ellipsoidal voids in the growth direction. These voids do not appear to hurt transport properties perpendicular to the film.

Finally, the group at Iowa State has systematically measured the hole mobility-lifetime-product as a function of Tauc gap in a-(Si,Ge): $\mathrm{H}$ produced by the glow-discharge techniques. In common with the results of the Oregon group, these results indicate that increasing Ge content leads to decreasing hole mobilitylifetime-products.

\section{Device Design}

Since the material properties of a-( $\mathrm{Si}, \mathrm{Ge}): \mathrm{H}$ are poorer than the properties of $\mathrm{a}-\mathrm{Si} \mathrm{H}$, the design of devices to improve hole transport becomes critical. The traditional method of improving hole transport is to use a graded bandgap scheme as shown in Fig. 6A [Guha et al. 1989] or 6B [Baldwin et al. 1993]. To overcome the problems of electron transport that arise in previous designs, Dalal has recently included a graded, parts-per-million diborane doping in the $i$ layer as shown in Fig. 6C. By doing such boron grading in the $i$ layer, the group at Iowa State was able to improve the fill factors of their devices from $57 \%$ to $64 \%$.
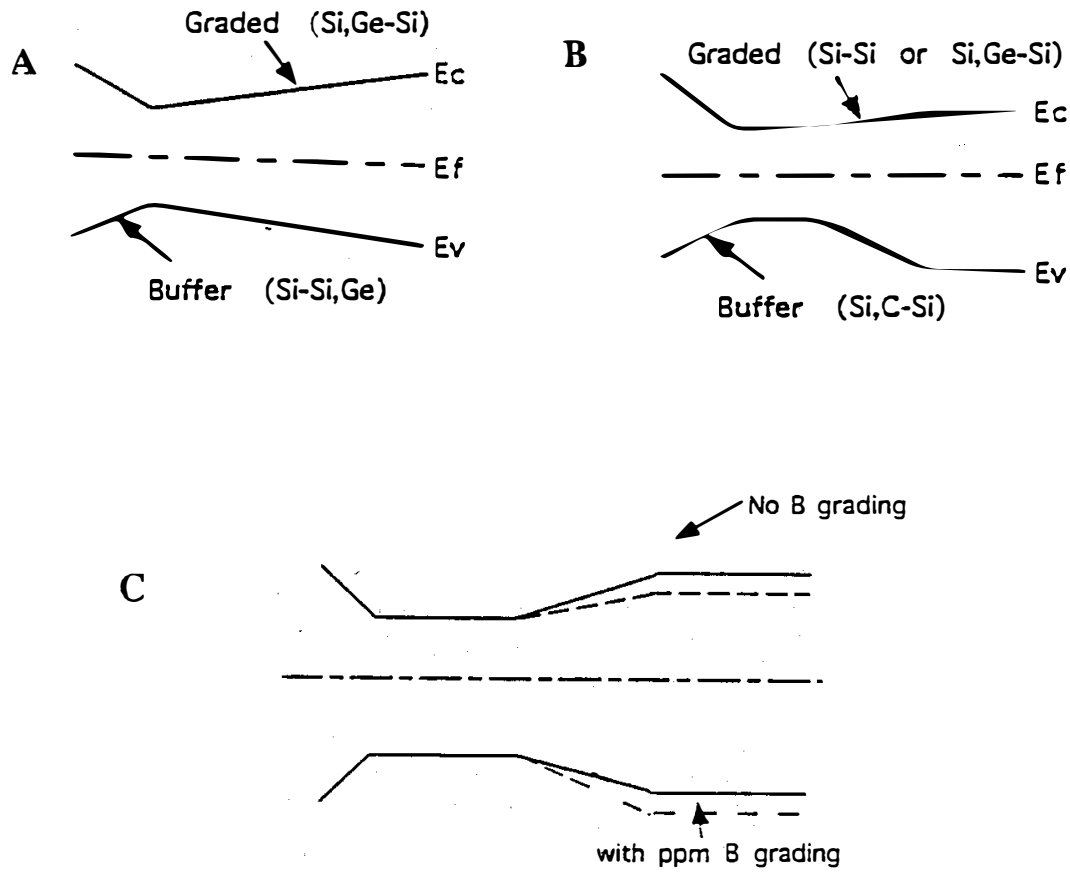

Figure 6. Different graded gap profiles used to make a-(Si,Ge):H solar cells. 
A novel method for improving fill factor was also used by S. Wagner's group at Princeton University. They used micro-doping of the $i$ layer to introduce sheets of charge in the $i$ layer, thereby changing the field profiles in the material and increase the field in the middle of the $i$ layer. The Princeton group simulated a cell using the AMPS model (see below in the next section), and then built a cell accordingly. They found that the fill factor reduction after light-induced degradation was less when they introduced these microsheets of charge in the $i$ layer.

\section{Device performance}

The best device performance continues to be from the USSC group [Guha et al. 1993]. Their best low-bandgap cell results are shown in Table 1. A particularly noteworthy achievement by the USSC group has been the fabrication of high performance a-(Si,Ge):H devices at very high growth rates $(10 \mathrm{~nm} / \mathrm{sec})$ [Guha et al. 1995]. They also achieved a near $100 \%$ gas utilization. This achievement is of major importance for commercialization of a-Si devices.

\section{Summary of progress}

In summary, significant progress has been made in developing better materials using novel growth techniques, in understanding of material properties, in improved device designs, and in fabrication of better cells at high growth rates. There seems little doubt that the team will be able to achieve the near term DOE target of a $12 \%$ efficient tandem or multi-junction module using a-Si: $\mathrm{H}$ and $\mathrm{a}-(\mathrm{Si}, \mathrm{Ge}): \mathrm{H}$. The newer materials and novel device designs are likely to be of significant help in achieving the longer term target of $15 \%$ efficiency.

\section{MULTLJUNCTION DEVICE TEAM}

The Multijunction (MJ) Device team seeks to improve a-Si module performance independent of specific $i$ layer bandgap or alloy. For example, the team effort is directed at aspects of the solar cell which are extemal to the a-Si semiconductor layers, such as the contacts, or to those which are common to all the devices, such as generic device modeling. The research priorities are listed in Figure 7.

Experimentally, the primary focus is to develop alternative transparent conductive oxide (TCO) materials with reduced parasitic absorption losses and good light scattering properties, and to develop more reflective rear contacts. Analytically, the focus is on determining the optimum device design for a $15 \%$ stabilized efficiency MJ device, obtaining material and device parameters for better modeling, and incorporating realistic light trapping models into electrical device models. Note that more efficient photon utilization (less TCO absorption, better light trapping, and a more reflective back contact) has an impact far beyond generating higher short-circuit current density $\left(\mathrm{J}_{\mathrm{sc}}\right)$. Increasing the photons 


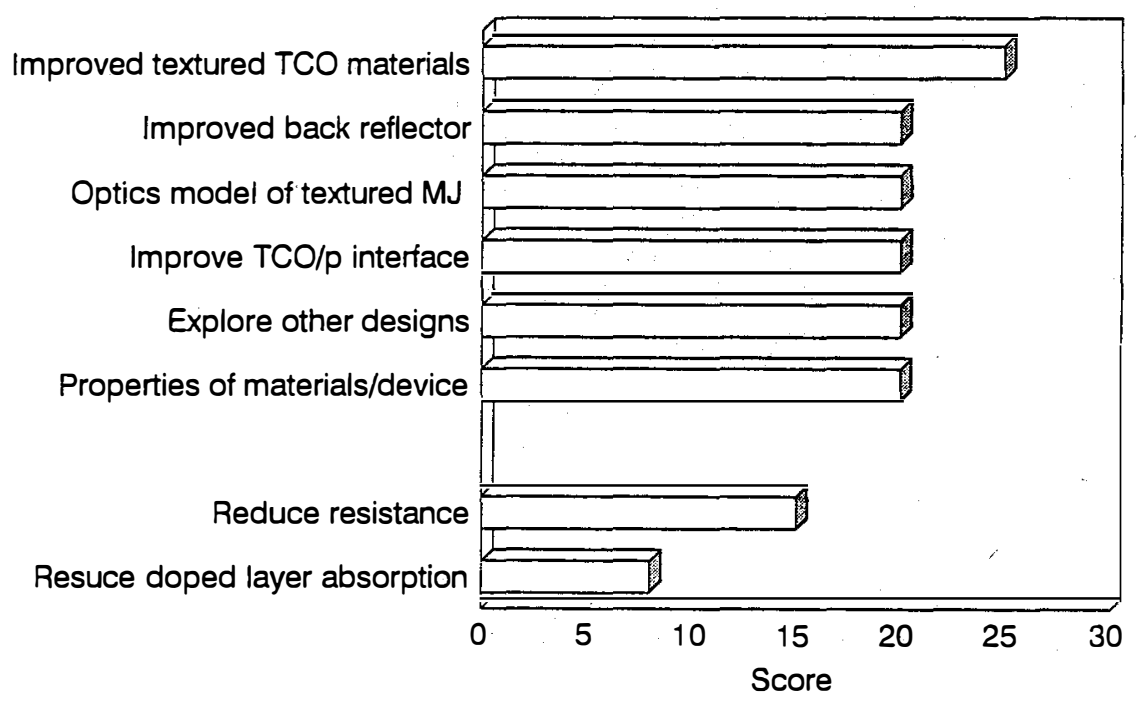

Figure 7. Multijunction device team research priorities

absorbed in a given $i$ layer allows that layer to be thinner yet still generate the same current. Making the $i$ layer thinner improves stability and reduces deposition time. These latter two benefits may be greater driving forces for improving optical absorption efficiency in a given $i$ layer than increasing the $\mathrm{J}_{\mathrm{sc}}$.

Two different MJ device configurations have evolved in the a-Si PV industry. Superstrate devices (glass substrate/textured TCO/p-i-n/p-i-n/smooth $\mathrm{TCO} /$ metal) are made by Solarex, Utility Photovoltaic Group, and Advanced Photovoltaic Systems. Substrate devices (stainless steel substrate/textured Ag/smooth $\mathrm{TCO} / n-i-p / n-i-p / n-i-p /$ smooth TCO) are made by Energy Conversion Devices and United Solar Systems Corporation.

MJ team research relating to improved textured TCO materials for superstrate cells involves deposition of single- and double-layer TCO materials and evaluation of their optical and electrical properties. Textured $\mathrm{SnO}_{2}$ has been the industry standard but has two weaknesses. Its transparency is reduced under exposure to a reactive plasma due to chemical reduction. This causes a thin layer of highly absorbing Sn to be formed [Schade et al., 1984]. Furthermore, it has a peak transmission of only approximately $94 \%$ in the visible spectral range.

Researchers have tried to get around these two problems by developing a very thin $(10-20 \mathrm{~nm})$ transparent protective coating for the $\mathrm{SnO}_{2}$, and by developing alternative bulk TCO materials like $\mathrm{ZnO}$. While $\mathrm{ZnO}$ is more transparent (97\%) and more stable under plasma exposure than $\mathrm{SnO}_{2}$, many groups worldwide have found it difficult to make low resistance $\mathrm{ZnO} / p$ contacts [Kubon et al., 1994]. Solarex has improved the $\mathrm{J}_{\mathrm{sc}}$ of tandem a-Si/a-SiGe devices by nearly $1 \mathrm{~mA} / \mathrm{cm}^{2}$ using textured $\mathrm{ZnO}$ having higher transparency compared to textured $\mathrm{SnO}_{2}$ (Arya et al., 1994).

The thermal and plasma stability of textured TCO materials were evaluated [S. 
Hegedus, et al. 1995]. The TCO materials included single layers of textured $\mathrm{SnO}_{2}: \mathrm{F}$ (APCVD), $\mathrm{ZnO}: \mathrm{F}$ (APCVD), $\mathrm{ZnO}: \mathrm{B}$ (LPCVD) and double layers of textured $\mathrm{SnO}_{2}: \mathrm{F}$ coated with thin layers $\left(<100 \mathrm{~nm}\right.$ ) of $\mathrm{ZnO}: \mathrm{Al}$ (sputtered) or $\mathrm{TiO}_{2}$ (APCVD). All of the $\mathrm{ZnO}$ films, and $\mathrm{SnO}_{2}$ films coated with thin layers of $\mathrm{ZnO}$ and $\mathrm{TiO}_{2}$, were largely stable against $\mathrm{H}_{2}$ plasma exposure. However, single-layer $\mathrm{SnO}_{2}$ showed increased absorption in range of $400-1000 \mathrm{~nm}$, as expected. A new result was that the resistivity of the LPCVD $\mathrm{ZnO}$ films increases by 3-8 times when heated at $250^{\circ} \mathrm{C}$ for 1 hour in air or under vacuum. This explains why lowresistance contacts may be more difficult to make with LPCVD $\mathrm{ZnO}$ unless processing temperatures are kept below $250^{\circ} \mathrm{C}$. APCVD ZnO, which is deposited above $400^{\circ} \mathrm{C}$, was the only material found to be stable against both thermal annealing and $\mathrm{H}_{2}$ plasma. Future work will involve developing $\mathrm{ZnO}$ films by either LPCVD or APCVD with lower sheet resistance $(<10 \mathrm{ohms} / \mathrm{sq}$.) without sacrificing transparency ( $>95 \%$ peak around $550-600 \mathrm{~nm}$ ).

Light trapping also requires a very highly reflective back contact to allow multiple passes without significant absorption losses. This increases $\mathrm{J}_{\mathrm{sc}}$ by enhancing the long wavelength quantum efficiency. Analysis of both superstrate and substrate devices indicates considerable losses in $\mathrm{J}_{\mathrm{sc}}\left(2-4 \mathrm{~mA} / \mathrm{cm}^{2}\right)$ which are attributed to a parasitic absorption at the back reflector.

The most common reflective back contact for superstrate devices has been $\mathrm{ZnO} / \mathrm{Ag}$. However, Solarex found that red response of devices with $\mathrm{ZnO} / \mathrm{Ag}$ decreased over time due to degradation of the reflectance of the $\mathrm{ZnO} / \mathrm{Ag}$ back contact [Li et al., 1994]. Solarex has developed a back contact using LPCVD $\mathrm{ZnO}$ with an $\mathrm{Al}$ reflector instead of an $\mathrm{Ag}$ reflector [Arya et al., 1994]. The new reflective $\mathrm{ZnO} / \mathrm{Al}$ contact is more stable and also greatly improves module yield by reducing shunts. Another approach to increase the scattering is to have double-textured devices. Besides the conventional textured front TCO layer, the rear TCO could be textured as well, leading to increased scattering and absorption of weakly absorbed photons. The group at United Solar Systems Corporation (USSC) has developed a SS/textured $\mathrm{Ag} / \mathrm{ZnO}$ back contact for their substrate-type devices. USSC has compared this improved reflector to bare stainless steel (SS) using an a-SiGe bottom cell measured under the appropriately filtered (red) illumination. The $\mathrm{J}_{\mathrm{sc}}$ under red light doubled from 5 to $10 \mathrm{~mA} / \mathrm{cm}^{2}$ with the improved reflector, and the net power output increased from 2.3 to $4.4 \mathrm{~mW} / \mathrm{cm}^{2}$. USSC compared different types of texture for the back reflective contact of their substrate-type devices [Banerjee, 1994]. Further improvements are expected by reducing parasitic absorption losses associated with the $\mathrm{SS} / \mathrm{Ag} / \mathrm{ZnO}$ back contact structure, which is the subject of ongoing research at USSC. Photothermal deflection spectroscopy has been applied by Energy Conversion Devices (ECD) to characterize the back reflector for substrate devices. This lead to their development of a hot $\mathrm{Ag} / \mathrm{cold} \mathrm{Ag} / \mathrm{ZnO}$ back contact in which the texture is provided by the bottom Ag layer deposited at high temperature and low growth rate while the reflectivity is provided by top $\mathrm{Ag}$ layer deposited at low 
temperature and high deposition rate [Deng and Narasimhan, 1994].

The relative importance of bulk $i$ layer $v s$. interface losses is still a matter of considerable debate, with some groups showing that most solar cell behavior can be explained by bulk phenomena ( $i$ layer recombination) while experiments by others identify interface losses as critical. This applies to initial as well as light-soaked behavior. The ECD group [Deng and Jones, 1995] fabricated $n-i-p$ and Schottky devices (c-Si $n$ layer/a-Si $i$ layer/Pd) having $i$ layers with a range of thickness and Ge content. They found good correlation between the fill factor (FF) of both types of devices over a wide range of FF. Since the two types of devices have no interfaces in common, just their $i$ layer, this suggests that FF is governed by $i$ layer properties, not by interfaces.

Modelling with the Analysis of Microelectronic and Photonic Structures (AMPS) computer simulation code at Penn State University (S. Fonash) has provided insight into optimizing the design of the triple-junction cells to achieve the $15 \%$ stabilized efficiency goal. Using parameters representing present day a-Si based materials, the Penn State University group [Bae and Fonash, 1994] found that the best material for the high bandgap $(1.8 \mathrm{eV})$ top cell of a triple-junction is a-Si, not a-SiC alloy as previously thought. AMPS modeling also indicates that optimization for stabilized efficiency requires very thin absorbing $i$ layers in each junction. The top cell must be very thin (less than $80 \mathrm{~nm}$ ); however, the most dramatic reduction in thickness must come in the middle-bandgap cell. With such thin absorbing $i$ layers, the following issues become critical: minimizing optical impedance matching losses for incident light (front reflection losses); improved light trapping; and reduced shorting/shunting effects caused by texture and topography of the underlying substrate in conventional cell designs. This lead the Penn State University group to propose altemative device structures having front TCO contacts with well-controlled (but milder) texture compensated with external rear textured contacts.

In addition to the detailed modeling based on first-principles solution to transport equations with microscopic material parameters as input such as AMPS, simpler equivalent circuit models for MJ solar cells are being used to guide the design and to understand experimental results. Lumped-circuit models of MJ devices have been used by Solarex [Li et al., 1994] to explore why current mismatch increases the overall FF. They found that when the junction with the lowest FF has the largest light generated current, the overall FF of the MJ device improves, but the net power output does not. Researchers at IEC (Hegedus and Phillips, 1994) have shown that the illuminated $\mathrm{J}-\mathrm{V}$ characteristic of a-Si devices can be accurately represented with a six-parameter model. The parameters are determined directly from light and dark J-V data. This technique has been applied to a-Si and a-SiGe single-junction devices from USSC and Solarex in initial and light soaked states to extract device parameters which are being used to model MJ devices.

Amorphous silicon solar cells require texture to provide efficient light trapping. The optical behavior of thin-film solar cells on textured substrates is quite 
complicated due to scattering and multiple internal reflections at non-planar interfaces. Typically, the design of the texture is empirical because of difficulty in analyzing the interaction of light at non-planar surfaces. Some simplifications are possible when the cell dimensions are either much larger or much smaller compared to the wavelengths of interest. These simplifications are not valid when the wavelengths are comparable to the solar cell dimensions and the texture features. A group at NREL (B. Sopori) is developing a wave theory analysis based on a rigorous solution to Maxwell's equations and the appropriate boundary conditions. They solve for the $\mathbf{E}$ and $\mathbf{H}$ fields inside and outside of the solar cell layers to determine the reflected, transmitted, and absorbed energy at each wavelength. The code has been written and is being verified by comparison to measured optical data on a-Si layers and solar cells.

The long term goal is to incorporate this optical model into an electrical model such as AMPS to provide an accurate tool for designing MJ a-Si devices on textured substrates. This will also aid in understanding experimental results by relating generation and collection to the physical, electronic, and optical parameters of the MJ device.

\section{CONCLUSIONS}

Preparing development plans for each of the four teams has focussed the research effort and is facilitating coordination by clearly indicating the team member responsible for specific research goals. Research priorities have been established by consensus and the highest priority items are actively pursued. Some of the technical accomplishments during the last year are: Wide-bandgap team: higher open-circuit voltages have been achieved, a new BP film with improved transparency has been prepared, and higher (1\%) nano-void fraction for a-SiC:H films has been confirmed for many films. Mid-bandgap team: promising stability of a-Si:H:F cells has been observed, Schottky barrier cell have been confirmed as a tool for rapid material quality determination, a two-step hydrogen dilution deposition to improve stability and reduce deposition time has been developed, improved fill factors and open-circuit voltage for hot-wire devices have been achieved, lower defect post-light-soaking density for $2 \%$ hydrogen hot-wire films and better stability for electron-cyclotron-resonance deposited devices were obtained, and electroluminescence has elucidated differences in H-diluted films from non $\mathrm{H}$-diluted ones. Low-bandgap team: new material deposition techniques are producing better materials, microcrystalline silicon for the low-bandgap component cell was demonstrated and interface problems were identified, high-rate $(10 \mathrm{~nm} / \mathrm{s})$ deposition of efficient $(11.4 \%$ initial) solar cell were demonstrated, it was determined that oriented ellipsoid microvoids in a-SiGe:H do not degrade electronic properties, cooperation was established between Harvard University and Energy Conversion Devices, Inc. on modifying the low-defect density Harvard a- 
SiGe:H material to improve hole transport, and boron compensation strategies appear to be beneficial in improving performance. Multijunction device team: evaluated devices on a new textured $\mathrm{ZnO}$ front contact, confirmed stability to plasma for all $\mathrm{ZnO}$ materials as front contact, developed a new $\mathrm{Hot} \mathrm{Ag} / \mathrm{Cold} \mathrm{Ag}$ back reflector for improved light trapping, and started preparation of new device structure for planar semiconductor layers with an external reflector.

\section{ACKNOWLEDGEMENTS}

This work was performed under Contract No. DE-AC02-83CH10093 to the U.S. Department of Energy. The authors acknowledge the contributions by the amorphous silicon team members: J. Abelson, R. Arya, R. Biswas, R. Braunstein, D. Cohen, R. Collins, R. Crandall, X. Deng, S. Fonash, A. Gallagher, R. Gordon, S. Guha, D. Han, S. Jones, M. Li, Mackamul, H. Mahan, N. Maley, B. Nelson, B. Sopori, S. Wagner, Q. Wang, D. Williamson, C. Wronski, J. Yang, L. Yang,

\section{REFERENCES}

Arya, R., R. Oswald. Y. Li, N. Maley, K. Jansen, L. Yang, L. Chen, F. Willing, M. Bennett, J. Morris, and D. Carlson, "Progress in Amorphous Silicon-based Multijunction Modules," Conference Record of the 24th IEEE Photovoltaic Specialists Conference, 1994, pp. 395-400.

Bae, S., and S. Fonash, "Examination of Optimized Structures for a-Si:H-based Triple-junction Solar Cells," Conference Record of the 24th IEEE Photovoltaic Specialists Conference, 1994, pp. 484-487.

Baldwin, G., V. L. Dalal and K. Han, "Deposition of high-quality a-SiGe:H films and novel graded-gap devices using if triode glow discharge deposition," Conference Record of the 23nd IEEE PV Specialists Conference, 1993, p.1037-1042.

Banerjee, A., J. Yang, K. Hoffman, and S. Guha, Applied Physics Letters, 65, 1994, 472.

Collins, R. W., Lu. Y., An, I., H. V. Nguyen, and Wronski, C. R., in Amorphous Silicon Technology-1995, edited by M. Hack, et al, (Materials Research Society, Pittsburgh, 1995), Mat. Res. Soc. Symp. Proc., 377, 1995, in press.

Crandall, R. S. and E.A. Schiff, "Correlation of open-circuit voltage and optical bandgap in amorphous silicon-based solar cell," in these proceedings, 1995.

Dalal, V. L.. E. X. Ping, S. Kaushal, M. Leonard, M. Bhan and K. Han, "Growth of amorphous silicon materials and devices with improved stability," Mat. Res. Soc. Symp. Proc. Vol. 336, 1994, pp. 335-340.

Deng, X., and S. Jones, "c-Si(n+)/a-Si alloy/Pd Schottky Barrier Device for the Effective 
Evaluation of Photovoltaic Performance of a-Si Alloy Materials," presented at 1995 Spring MRS Meeting, Symp. on a-Si Technology, Mat. Res. Soc. Symp. Proc., 377, 1995. In press.

Deng, X., and K. Narasimhan. "New Evaluation Technique for Thin-film Solar Cell Back-reflector using Photothermal Deflection Spectroscopy," Conference record of the 24th IEEE Photovoltaic Specialists Conference, 1994. pp. 555-558.

Deng, X., 1995 Annual Technical Report, "Development of high, stable-efficiency, triole-junction a-Si alloy solar cells," NREL subcontract ZAN-4-13318-11.

Guha, S., J. Yang, A. Banerjee, T. Glatfelter, K. Hoffman, and X. Xu, "Progress in Multijunction Amorphous Silicon Alloy-based Solar Cells and Modules", Proceedings 7th International PVSEC Conf., PVSEC-7, 1993.

Guha, S., J. Yang, A. Pawlikiewicz, T. Glatfelter, R. Ross and S. Ovshinsky, Appl. Phys. Lett. 54, 2330 (1989)

Guha, S., J. Yang, A. Banerjee, Appl. Phys. Lett. 66, 595 (1995)

Hegedus, S., H. Liang, and R. Gordon, "Transparent Conducting Oxides (TCOs) for Amorphous Silicon Solar Cells," these proceedings, 1995.

Hegedus, S., and J. Phillips. "Parametric Analysis of Amorphous-Silicon Solar Cells from CurrentVoltage Measurements," Conference Record of the 24thIEEE Photovoltaic Specialists Conference. 1994, pp. 654-657.

Kubon, M., E. Boehmer, M. Gastel, F. Siebke, W. Beyer, C. Beneking, and H. Wagner." Solutions of the $\mathrm{ZnO} / \mathrm{p}$ contact problem in a-Si:H Solar Cells," Conference Record of the 24th IEEE Photovoltaic Specialists Conference, 1994, pp. 500-503.

Kwon, D., J.D. Cohen. B.P. Nelson, and E. Iwaneiczko, "Effect of Light-Soaking on Hot WireDeposited a-Si:H Films," Mat. Res. Soc. Symp. Proc., 377, 1995, Spring Meeting, in press.

Li, Y., L. Yang, M. Bennett, L. Chen, F. Jackson, K. Rajan. and R. Arya, "A Study of a-Si:H/aSiGe:H Tandem Solar Cells and Modules," Mat. Res. Soc. Symp. Proc., Vol. 336; 1994, pp. 723.

Li, Y.-M., "Amorphous silicon-carbon alloys for solar cells," Mat. Res. Soc. Symp. Proc. Vol. 297, 1993, pp. 803-814.

Luft, W., "NREL/Industry Interaction: Amorphous Silicon Research Team Formation," AIP Conference Proceedings No. 306 of the 12th NREL PV Program Review Meeting, 1993, pp. 46-50.

Mahan, H., et al., "Hot-Wire-Deposited Hydrogenated Amorphous Silicon Solar Cells." 13th NREL PV Program Review Meeting, these proceedings, 1995

Mahan, A.H., J. Carapella, B. Nelson, R. Crandall and I. Balberg, J. Appl. Phys. 69, 6728 (1991)

Peterson, T., and W. Luft. "Adopting a customer-focused team approach to amorphous silicon multijunction module R\&D", Conference Record of the 23nd IEEE PV Specialists Conference. 1993, pp. 950-954. 
Schade, H., Z Smith, J. Thomas III, and A. Catalano, Thin Solid Films, 117, 1984. pp. 149.

Wang, Q., Y. Xu, and R.S. Crandall, "Role of Hydrogen Dilution in a-Si:H p-i-n Solar Cell Stability," 13th NREL PV Program Review Meeting, these proceedings, 1995

Wang, Q., Schiff, E. A., and Hegedus, S., "Built-in potentials via electroabsorption measurements in a-Si:H p-i-n solar cells: A critical assessment," Mat. Res. Soc. Symp. Proc. Vol. 336, 1994, pp. 365-370.

Williamson, D., A. H. Mahan, B. P Nelson and R. Crandall, Appl. Phys. Lett. 55, 783 (1989)

Williamson. D. L., in Amorphous Silicon Technology-1995, edited by M. Hack et al., (Materials Research Society, Pittsburgh, 1995), Mat. Res. Soc. Symp. Proc., 377, 1995, in press.

Yang, J., Xu, X., and Guha, S., "Stability studies of hydrogenated amorphous silicon alloy solar cells prepared with hydrogen dilution," Mat. Res. Soc. Symp. Proc. Vol. 336, 1994, pp. 687-692.

Yang, $\mathrm{L}$ and L. Chen, "The Effect of $\mathrm{H}_{2}$ Dilution on the Stability of a-Si:H Based Solar Cells," Mat. Res. Soc. Symp. Proc. Vol. 336, 1994, p. 669-674

Zhong, F., J. D. Cohen, J. Yang and S. Guha, "The electronic structure of a-Si,Ge:H alloys," Mat. Res. Soc. Symp. Proc. Vol. 336, 1994, pp.493-498.

Zhong, F., C.-C. Chen, D. Cohen, P. Wickboldt, and W. Paul, "Defect properties of cathode deposited glow discharge amorphous silicon-germanium alloys," in Amorphous Silicon Technology1995, edited by M. Hack, et al.. (Materials Research Society, Pittsburgh, 1995), Mat. Res. Soc. Symp. Proc., 377, 1995, in press. 